Vasylieva, T., Jurgilewicz, O., Poliakh, S., Tvaronavičienė, M., \& Hydzik P.

(2020). Problems of measuring country's financial security. Journal of International

Studies, 13(2), 329-346. doi:10.14254/2071-8330.2020/13-2/22

of International

Studies

\title{
Problems of measuring country's financial security
}

(c) Foundation

of International

Studies, 2020

(c) CSR, 2020

\section{Tetyana Vasylieva}

Department of Finance and Entrepreneurship,

Sumy State University,

Ukraine

tavasilyeva@,fem.sumdu.edu.ua

\section{Oktawia Jurgilewicz}

Faculty of Management,

Rzeszow University of Technology,

Rzeszow, Poland

niemieco@pra.edu.pl

\section{Sergii Poliakh}

Department of Finance and Banking,

Cherkasy Educational and Scientific Institute of Banking University,

Ukraine

poliakbchibs@ukr.net

\section{Manuela Tvaronavičienè}

The General Jonas Zemaitis Military Academy of Lithuania,

Vilnius, Lithuania

manuela.tvaronaviciene@,vgtu.lt

\section{Paweł Hydzik}

Faculty of Management

Rzeszow University of Technology,

Rzeszow, Poland

phydzik@,prz.edu.pl

Abstract. The aim is to define the key issues ensuring financial security of a country.

The studies proposes a technique to calculate a country's quality management index for a financial as a weighted average of the country's overall compliance with key international standards, rules and principles in the sector. The study uses statistical information from the Consultative Group to Assist the Poor, the World 
Development, to study financial security of the population in 142 countries with different levels of economic development. 47 variables, grouped into 10 aggregates, were included in the study: Disclosure of information upon opening a deposit account, Disclosure of information upon opening a credit account, Disclosure of general information, Periodic disclosure upon opening deposit accounts, Periodic disclosure Monitoring, Enforcing, Fair treatment, Recourses, Standards for complaints resolution. Analysis of the results show that the levels of financial security in the studied countries have a wide variation from the minimum to the maximum values. We see that among the countries with high levels of economic development, the leaders are Italy, Canada and Puerto Rico. Transition economies include Venezuela, Argentina and Mexico; among developing countries, we can mention Armenia, Azerbaijan and Uzbekistan.

Keywords: financial involvement, financial security, financial market, financial service, financial institute.

JEL Classification: G00, G28, G30

\section{INTRODUCTION}

General issues related to the definition of the conceptual framework for financial security began to be discussed at the edge between the XXth and XXIst centuries, particularly during the period when common European financial and economic space was emerging. As a result, a number of regulatory documents have been developed by international organizations to set out the main provisions for regulating consumer rights at the financial services market in general and in the banking system as one of the key sectors in the financial market in particular. Most of contemporary scientists around the world during their study of the core indicators of the banking sector consumer protection, consider ten basic principles developed by the Financial Markets Committee of the Organization for Economic Co-operation and Development (in collaboration with the Financial Stability Board (FSB)) commissioned by the Ministers of Finance and the central banks of the G20 countries. These principles provide definitions for the role of internal and external financial institutions, openness and transparency of financial information, responsible business behaviour of financial service providers and authorized agents, protection of consumer assets and consumer personal information against fraud and abuse.

However, these provisions are of a recommendatory nature and do not provide an opportunity to obtain a comprehensive assessment of the country's financial security. The lack of a universal methodology of measuring the country's financial security actualizes this research. Thus, the aim of the article is defining the key issues ensuring financial security of a country. In the context of this goal, the study should test the main hypothesis regarding the presence of a direct relationship between countries 'economic development level and the level of financial security. The article consists of three main parts. The first part analyzes the existing research on a particular topic. The concept of financial security is considered differently by different groups of researchers which, on the one hand, are thinking financial security is a complex category that is formed under the influence of economic, social and financial determinants, and on the other - the public administration level and involves the use of the concept of a new public management. The second part of the article deals with the selection and use of methods for determining the integrated index of financial security. In the third part, a model is built and a hypothesis is tested regarding the presence of a link between financial security and the level of economic development of the country. 


\section{LITERATURE REVIEW}

"Good Practices for Financial Consumer Protection" was one of the most well-known projects prepared by World Bank specialists headed by Susan L. Roultge, Senior Specialist for Private Sector in 2012. These "practices" form instruction on how to organize the level of financial security as effectively as possible. The work consists of three parts. The first part presents a detailed analysis of existing international measures aimed at improving the process to protect the financial environment. The second part gives a list of 39 common practices that should ensure the effective functioning of the country's financial security system.

A number of scholars have considered the key economic, social and financial determinants in their work that form the basis for a secure financial environment: (Kuzmenko \& Kyrkach, 2014), Petrushenko et al., 2014, 2018), (Dave, 2017a, b), (Bilan et al., 2018, 2019a), (Buriak et al., 2015), (Buriak et al, 2019), (Gavurova et al., 2017), (Grybaitè and Stankevičienè, 2018), (Kwilinski et al., 2019), (Li and Ouyang, 2019), (Kostyuchenko et al., 2018), (Njegovanović, 2019), (Pitoňáková, 2019), (Simionescu et al., 2019), (Vasilyeva et al., 2016), (Yakubu et al., 2019), (Jurgilewicz, 2019), (Aqil et al.).

A significant step in creating favourable conditions for regulating a financially secure environment in the European space was the development of the Markets in Financial Instruments Directive (MiFID) in 2004 by Financial Services Authority (FSA), the activity of which was subsequently extended to the European Union countries in 2007. This Directive is the successor to the earlier Investment Services Directive (ISD) since May 1993, which became obsolete due to the establishment of European Union as a powerful player in the international financial sector and complicating the process to control stakeholders' activity presented therein. However, in the future, the first MiFID has been amended and supplemented by some points, and as a result, there is an active version - MiFID II.

The main objective to create the Directive, starting with its first version of MiFID, was to ensure the effective functioning of the single European financial market, based on the principles of fairness, transparency and efficiency.

The key provisions of this Directive include:

- expanding the international activity of investment companies by opening their branches in different European countries;

- formation of an extended range of investment products and services that require authorization;

- introduction of enhanced control over the financial recommendations of brokerage companies and the disclosure of key information regarding investment products;

- the necessity to maximize information on the services and possible market risks of all entities in the European financial market.

In addition, it should be noted that the MiFID II Directive also affects non-member countries of the European Union. In particular, increasing the market transparency level for all asset classes will enable nonEuropean Union organizations to focus their activities on the European market; if the head office of the company is in a non-European Union country, and its main activity is in the European market, it implies compliance with the best management practices.

In the works of (Alshubiri, 2019), (Khan et al, 2017,2018), (Bilan et al, 2019b), (Derevyanko et al, 2019), (Natocheeva et al, 2019), (Piontek, 2019), (Ramazanova et al, 2019), (Straßberger \& Sysoyeva, 2016), (Logan \& Esmanov, 2017), (Morscher et al., 2017), (Boiko et al, 2019), (Plastun et al., 2018) the country's financial security is considered at the public administration level and involves the use of the concept of a new public management. The synchronization of business cycles and financial cycles is one of the leading topics in modern economic studies. Identifying these cycles enables us to investigate the specific nature of a country's 
financial environment, taking into account its weaknesses: (Bilan et al, 2019b, 2019c), (Brychko \& Olejarz, 2019), (Belas et al., 2019), (Korcsmáros \& Šimova, 2018), (Levchenko et al., 2019), (Pansuwong, 2020), (Vasilyeva et al., 2019, 2020), (Shvindina, 2019), (Ch \& Semenog, 2017), (Vasylyeva et al., 2014). There are much attention into the usage of mathematical instruments for computing the level of financial determinants (Kostel et al., 2017), (Louis, 2017), (Sukhonos \& Makarenko, 2017), (Yelnikova, 2014), (Brychko, 2013), (Lieonov et al., 2019).

In their work, researchers pay much attention to the specific features of ensuring a high level of financial security for a particular country or region, taking into account their economic and geopolitical situation: Slovakia (Martin \& Zimková, 2018) (Korcsmaros et al., 2018, 2019), Latin America (CortésSánchez \& Rivera, 2019), Indonesia (Evana et al., 2019), Central and Eastern Europe (GrenÄ et al., 2019), Ukraine (Horská et al, 2019), (Shkvarchuk \& Slav'yuk, 2019), (Bojarko et al., 2012), the USA (Kasztelnik and Brown, 2019), (Kasztelnik and Gaines, 2019), EU countries (Kisel'áková et al., 2019), Sudan (Abdalla and Ahmed, 2018), post-Soviet countries Ouro (Naghshpour, 2019), (Grenčíková et al., 2019), Russia (Pilipenko et al., 2019), Lithuania (Remeikienè et al., 2019), Kosovo (Shkodra, 2019).

Financial security of the country as a dynamic phenomenon, determined by such factors as financial literacy of the population, the level of the shadow economy development, the activities of insurance, banking and other financial companies, the stock market is reflected in the following works: (Boyko \& Roienko, 2014 ), (Horsch, 2018), (Leonov et al., 2014, 2019), (Lyeonov \& Liuta, 2016), (Lyeonov et al., 2019), (Sebestova et al., 2018), (Shapovalova et al., 2019), (Stefko et al., 2019), (Tsvetkova et al., 2019), (Vasileva\& Lasukova, 2013), (Sheng et al., 2019), (Yakymova \& Kuz, 2019), (Ch \& Semenog, 2017), (Djalilov, et al., 2015), (Li \& Ouyang, 2019).

\section{METHODOLOGY}

The study used statistical information from the Consultative Group to Assist the Poor, (CGAP), the World Bank Database (Financial Access 2010, Global Findex, G20 - Financial Involvement Indicators) and the Organization for Economic Co-operation and Development, related to the study of financial security of the population in 142 countries with different levels of economic development. The study comprised the main aspects of the financial security system: the sphere of the existing legal framework; supervisory and executive powers; regression mechanisms. The information in this database was used to assess the financial security of the world.

The methodology underlying the evaluation was proposed in V. Sandararayan's (Yossifov et al., 2003) work during the interregional analysis of the level of the financial system transparency in different countries. Then, this technique was actively used by various researchers to solve various problems in the sectors of the economy. The essence of this method is to calculate the country's quality management index for the financial or any other market as a weighted average of the country's full compliance with key international standards, rules and principles in the given segment.

The Regulatory Governance Quality Index (RGI) for the separate country will be shown in the following way:

$$
\begin{aligned}
& \mathrm{RGI}=\frac{1}{\mathrm{n}}\left(\sum \mathrm{SCORE}_{j}\right) \\
& j=[1, n]
\end{aligned},
$$

where $n$ - number of standards, used to get the index;

$j$ - concrete set of standards;

SCORE - an assessment of compliance with each standard, using a weighting scheme. 


$$
\operatorname{SCORE}_{j}=\left\lfloor 0 \cdot n c_{j}+0,33 \cdot p c_{j}+0,66 \cdot b c_{j}+f c_{j}\right\rfloor \cdot 100,
$$

where for each standard, the degree of compliance by its country is determined as follows:

$1=n c$ (noncompliance) - number of noncompliance provisions;

$2=p c$ (partial compliance $)-$ number of partial compliance provisions;

$3=b c$ (broad compliance) - number of broad compliance provisions;

$4=f c$ (full compliance) - number of full compliance provisions;

$9=$ not applicable/not answered - no data available.

According to the demonstrated technique in the research, only significant evaluations are taken into account (for example, items, for which no data are available for the country, are not included in the list used in the assessment).

In our case, the country's financial security (QP) level will be calculated as follows:

$$
\mathrm{QP}=\frac{1}{10}\left(\sum \operatorname{SCORE}_{10}\right)
$$

SCORE consists of ten indicators, which in turn include the following indices (Table 1).

An example of input indices, which are used to define the level of financial security of countries is presented in Table 2 .

\section{EMPIRICAL RESULTS AND DISCUSSION}

The adhering degree of each indicator SCORE is defined by the following way (Table 3).

The country's level of financial security was assessed based on the calculation of SCORE for every country and then a complex indicator was calculated. The calculation results for the studied countries are presented in the following figures (Figs. 1a, 1b, 1c).

Having analyzed the obtained level of financial security in the studied countries, we can see that Italy (864), Canada (797) and Puerto Rico (797) are leaders among the countries with a high level of economic development. Transition economies include Venezuela (831), Hungary (764), Argentina (763); among developing countries, there are Armenia (831), Azerbaijan (763) and Uzbekistan (730).

Thus, the highest level of financial security is observed in Italy, Armenia, Venezuela, Canada and Puerto Rico. Three of the five leading countries belong to developed countries, one to transition economies and one to developing countries. However, the nominal following of the calculated index does not mean that the consumers' interests in the financial services market in these countries are fully protected since its calculation is based only on financial security indicators. In our further studies, we will focus more on improving the proposed method to determine the country's financial security level by expanding the list of input indicators taking into account the internal aspects of the internal system functioning in the country.

The success of the financial sector development directly depends on the number of satisfied consumers involved. The reason for the financial instability of the country is the unwillingness of the population to accept the whole flow of financial information, which flows into life and constantly takes new forms. Financial policy, as a set of measures aimed at redistributing available resources in the financial system, must also ensure affordability, financial literacy, financial integrity and stability, which will certainly be the basis for protecting the interests of consumers in the financial services market. All of the above qualitative financial policy objectives require special attention from the regulator as they do not have a clear quantitative expression that could be compared with the reference value and draw conclusions about compliance / non- 
compliance with the set standards. However, many scientific studies have shown that affordability or, in other words, the level of financial involvement of the population has a direct positive relationship with financial stability, and this relationship is not one-sided.

However, nominal compliance with the calculated index QP does not mean that the interests of consumers in the financial services market in these countries are fully protected. Because its calculation is based only on financial security indicators. As mentioned above, financial security is a complex category. Therefore, in further research, we propose to adjust the QP index to the value of two criterias:

- readiness of consumers to be both active participants in the financial services market and to take a number of measures aimed at ensuring their rights, which is identified through the level of financial education of the adult population (readiness to be protected - RP);

- the actual involvement of the population in the financial services market is expressed through a group of indicators that characterize it (inclusion to the protection scheme - IP).

Thus, taking into account these criteria, we will be able to amend the QP index and prove the relationship between financial security and the level of economic development in the country.

\section{CONCLUSION}

According to the stated aim of the work, key problems to ensure the financial security of the country were identified. They are: to introduce the enhanced control over the financial recommendations of brokerage companies and the key information disclosure about financial products and services; the necessity to maximize information about services and the possible market risks of all financial market entities; to form a wide range of investment products and services that require authorization.

The study proposes a methodology for calculating a country's quality management index for a financial or any other market, as a weighted average of the country's overall compliance with key international standards, rules and principles in the segment. The study used statistical information from the Consultative Group to Assist the Poor, (CGAP), the World Bank Database (Financial Access 2010, Global Findex, G20 - Financial Involvement Indicators) and the Organization for Economic Co-operation and Development, related to the study of financial security of the population in 142 countries with different levels of economic development. A total of 47 variables, grouped into 10 aggregates, were included in the study: Monitoring, Enforcing, Fair treatment, Recourses, Standards for complaints resolution, Disclosure of information upon opening deposit, Disclosure of information upon opening credit, Disclosure of general information, Periodic disclosure upon opening deposit, Periodic disclosure upon opening credit. The analysis of the results showed that the obtained level of financial security in the studied countries has a wide variation from the minimum to the maximum value. We see that among the countries with a high level of economic development, the leaders are Italy, Canada and Puerto Rico. Transition economies include Venezuela, Argentina and Mexico; among developing countries, there are Armenia, Azerbaijan and Uzbekistan. Thus, in view of the analysis of the results obtained by all countries, the countries' economic development level does not play a key role in determining the maximum level of financial security, which indicates the presence of other determinants that need to be verified in future studies.

\section{ACKNOWLEDGEMENT}

The survey was supported by the Ministry of Education and Science of Ukraine and performed the results of the projects $0118 \mathrm{U} 003569$ and 0120U102001. 


\section{REFERENCES}

Alshubiri, F. N. (2019). Public finance indicators and the value of investment project development: a comparative study of GCC countries. Journal of Business Economics and Management,20(6), 1143-1167. doi:https://doi.org/10.3846/jbem.2019.10783.

Aqil, M., Ahmed, R. R., Vveinhardt, J., \& Streimikiene, D. (2019). Factors influencing the profitability of heavy vehicle industry: a case of Pakistan. Montenegrin Journal of Economics, 15(1), 61-72. doi:https://10.14254/18005845/2019.15-1.5.

Belas, J., Strnad, Z., Gavurova, B., \& Cepel, M. (2019). Business environment quality factors research-SME managements platform. Polish journal of management studies, 20(1), 64-77. doi:https://10.17512/pjms.2019.20.1.06.

Bilan, Y., Brychko, M., Buriak, A., \& Vasilyeva, T. (2019). Financial, business and trust cycles: the issues of synchronization. Zbornik Radova Ekonomski Fakultet u Rijeka, 37(1), 113-138. doi:https://doi.org/10.18045/zbefri.2019.1.113.

Bilan, Y., Lyeonov, S., Lyulyov, O., \& Pimonenko, T. (2019b). Brand management and macroeconomic stability of the country. Polish Journal of Management Studies, 19 (2), 61-74. doi:https://10.17512/pjms.2019.19.2.05.

Bilan, Y., Lyeonov, S., Vasylieva, T., \& Samusevych, Y. (2018). Does tax competition for capital define entrepreneurship trends in Eastern Europe? Online Journal Modelling the New Europe. 27(1), 34-66. doi:10.24193/OJMNE.2018.27.02.

Bilan, Y., Vasilyeva, T., Lyulyov, O., \& Pimonenko, T. (2019c). EU Vector of Ukraine Development: Linking Between Macroeconomic Stability and Social Progress. International Journal of Business \& Society, 20(2), 433 - 450. Retrieved from URL: http://www.ijbs.unimas.my/images/repository/pdf/Vol20-no2-paper1.pdf.

Bojarko, I. M., Deyneka, O. V., \& Hrytsenko, L. L. (2012). Methodological approach to estimation of quality of state regulation influence on Ukrainian financial services market. Actual Problems of Economics, (7), 183-190.

Boyko, A., \& Roienko, V. (2014). Risk assessment of using insurance companies in suspicious transactions. Economic Annals-XXI, (11-12), 73-76.

Brychko, M. (2013). Governance of stakeholder's financial relationships: Evidence fom Ukrainian banking sector. Corporate Ownership and Control, 11(1), 706-714.

Brychko, M., \& Olejarz, T. (2019). Trust cycle of the finance sector and its determinants: The case of Ukraine. Journal of International Studies, 12(4), 300 - 324. doi:10.14254/2071-8330.2019/12-4/20.

Buriak, A., Lyeonov, S., \& Vasylieva, T. (2015). Systematically Important Domestic Banks: An Indicator-Based Measurement Approach for the Ukrainian Banking System. Prague Economic Papers, 2015(6), 715728. doi:https://10.18267/i.pep.531.

Buriak, A., Vozńáková, I., Sułkowska, J., \& Kryvych, Y. (2019). Social trust and institutional (Bank) trust: Empirical evidence of interaction. Economics \& Sociology, 12(4), 116-332. doi:10.14254/2071-789X.2019/12-4/7.

Ch, A. R., \& Semenog A.Y. (2017). Non-bank financial institutions activity in the context of economic growth: crosscountry comparisons. Financial Markets, Institutions and Risks. 1(2), 39-49. doi:10.21272/fmir.1(2).39-49.2017.

Cortés-Sánchez, J. D., \& Rivera, L. (2019). Mission statements and financial performance in Latin-American firms. Business: Theory and Practice, 20, 270-283. doi:https://doi.org/10.3846/btp.2019.26.

Council Directive 93/22 on Investment Services in the Securities Field, 1993 O.J. (L 141) 27, corr. at 1993 O.J. (L 170) 32 and (L 194) 27 [hereinafter Investment Services Directive]. Retrieved from URL: https://eurlex.europa.eu/legal-content/EN/TXT/?uri=CELEX\%3A31993L0022.

Dave, H. (2017a). An Inquiry on Social Issues - Part 1. Business Ethics and Leadership, Volume 1, Issue 2, 78 - 87. doi:10.21272/bel.1(2).78-88.2017.

Dave, H. (2017b). An Inquiry on Social Issues - Part 2. Business Ethics and Leadership, Volume 1, Issue 3, 45 - 63. doi:10.21272/bel.1(3).45-63.2017.

Djalilov, K., Vasylieva, T., Lyeonov, S., \& Lasukova, A. (2015). Corporate social responsibility and bank performance in transition countries. Corporate Ownership and Control, 13(1CONT8), 879-888. doi:10.22495/cocv13i1c8p7.

Gavurova, B., Tkacova, A., \& Tucek, D. (2017). Determinants of Public Fund's Savings Formation via Public Procurement Process. Administration \& Public Management Review, (28), 25 - 44. Retrieved from URL: http://www.ramp.ase.ro/en/ data/files/articole/2017/28-02.pdf. 
Grenčíková, A., Bilan, Y., Samusevych, Y., \& Vysochyna, A. (2019). Drivers and inhibitors of entrepreneurship development in central and eastern European countries. In Proceedings of the 33rd International Business Information Management Association Conference, IBIMA (pp. 2536-2547). Retrieved from URL: https://ibima.org/acceptedpaper/drivers-and-inhibitors-of-entrepreneurship-development-in-central-and-eastern-european-countries/.

Grybaite, V., \& Stankevičienè, J. (2018). An empirical analysis of factors affecting sharing economy growth. Oeconomia Copernicana, 9(4), 635-654. doi:https://doi.org/10.24136/oc.2018.031.

Horsch, A., Sysoyeva, L., \& Bogma, S. (2018). Deposit insurance systems of post-Soviet countries: A comparative analysis. Journal of International Studies, 11(4), 22-44. doi:10.14254/2071-8330.2018/11-4/2.

Horská, E., Moroz, S., Polakova, Z., Nagyová, L', \& Paska, I. (2019). Evaluation of interaction between chosen indicators of development of regions in Ukraine. Equilibrium. Quarterly Journal of Economics and Economic Policy, 14(2), 341-357. doi:https://doi.org/10.24136/eq.2019.016.

Jurgilewicz, M., \& Jurgilewicz, O. (2019). Management of Information Security and its Protection in Criminal Matters: Case of Poland. Journal of Security \& Sustainability Issues, 8(3), $481 \quad$ - 491. doi:https://doi.org/10.9770/jssi.2019.8.3(15).

Khan, K., Qingyang, W., \& Khurshid, A. (2017). Causal relationship between monetary policy and the stock market: a bootstrap rolling window approach. Financial Markets, Institutions and Risks. 1(4), 5-15. doi:10.21272/fmir.1(4).515.2017.

Khan, Y. (2018). The Effectiveness of Entrepreneurial Activities for Economic Development: A Route to Innovation and Job Generation. SocioEconomic Challenges. Volume 2, Issue 2, 32 - 40. doi:10.21272/sec.2(2).32-40.2018.

Kiseláková, D., Šofranková, B., Onuferová, E., \& Čabinová, V. (2019). The evaluation of competitive position of EU28 economies with using global multi-criteria indices. Equilibrium. Quarterly Journal of Economics and Economic Policy, 14(3), 441-462. doi:https://doi.org/10.24136/eq.2019.021.

Korcsmáros, E., \& Šimova, M. (2018). Factors affecting the business environment of SMEs in Nitra region in Slovakia. Oeconomia Copernicana, 9(2), 309-331. doi:https://doi.org/10.24136/oc.2018.016

Korcsmaros, E., Seben, Z., Machova, R., \& Feher, L. (2019). Promotion of Euro Introduction in Slovakia: Financial Literacy of Generation $\mathrm{X}$ and $\mathrm{Y}$. Marketing and management of innovations, 3, 11-21. doi:https://10.21272/mmi.2019.3-01/.

Kostel, M., Leus, D., Cebotarenco, A., Mokrushina, A. (2017). The Sustainable Development Goals for Eastern Partnership Countries: Impact of Institutions. SocioEconomic Challenges, 1(3), 79-90. doi:https://10.21272/sec.1(3).79-90.2017.

Kostyuchenko, N., Starinskyi, M., Tiutiunyk, I., \& Kobushko, I. (2018). Methodical Approach to the Assessment of Risks Connected With the Legalization of the Proceeds of Crime. Montenegrin Journal of Economics, 14(4), 23-43. Montenegrin Journal of Economics, 14(4), 023-043. URL: doi:10.14254/1800-5845/2018.14-4.2.

Kuzmenko, O., \& Kyrkach, S. (2014). The use of regression analysis in the financial planning of banks, mathematical formalization of the stages of financial planning in banks. Mathematical Formalization of the Stages of Financial Planning in Banks (December 13, 2014).

Kwilinski, A., Tkachenko, V., \& Kuzior, A. (2019). Transparent Cognitive Technologies to Ensure Sustainable Society Development. Journal of Security \& Sustainability Issues, 9(2), $561 \quad$ - 570. doi:http://doi.org/10.9770/jssi.2019.9.2(15).

Leonov, S., Frolov, S., \& Plastun, V. (2014). Potential of institutional investors and stock market development as an alternative to households' savings allocation in banks. Ekonomichniy chasopys-XXI, (11-12), 65-68. Retrieved from URL: http://soskin.info/userfiles/file/2014/11-12 2014/Leonov Frolov Plastun.pdf.

Leonov, S., Yarovenko, H, Boiko, A.,. \& Dotsenko, T. (2019). Information system for monitoring banking transactions related to money laundering. CEUR Workshop Proceedings, 2422, 297-307. Retrieved from URL: http://ceurws.org/Vol-2422/paper24.pdf.

Levchenko, V., Boyko, A., Bozhenko, V., \& Mynenko, S. (2019). Money laundering risk in developing and transitive economies: analysis of cyclic component of time series. Business: Theory and Practice, 20, 492-508. doi:https://doi.org/10.3846/btp.2019.46. 
Li, P., \& Ouyang, Y. (2019). The dynamic impacts of financial development and human capital on CO2 emission intensity in China: an ARDL approach. Journal of Business Economics and Management, 20(5), 939-957. doi:https://doi.org/10.3846/jbem.2019.10509.

Lieonov, S. V., \& Isaieva, O. V. (2014). Determinants of government bond spreads in Ukraine and new EU members. Actual problems of economics, 5(155), 416-425.

Logan, W., \& Esmanov, O. (2017). Public financial services transparency. Business Ethics and Leadership, Vol. 1, Issue 2, 62-67. doi: $10.21272 /$ bel.1(2).62-67.2017.

Louis, R. (2017). A new economic order for global prosperity. SocioEconomic Challenges, (1, Iss. 2), 52-58. doi: $10.21272 /$ sec.1(2).52-59.2017.

Lyeonov, S., \& Liuta, O. (2016). Actual problems of finance teaching in Ukraine in the post-crisis period. In The Financial Crisis (pp. 145-152). Springer, Cham. doi:10.1007/978-3-319-20588-5 8.

Lyeonov, S., Bilan, Yu., Rubanov, P., \& Grenčíková, A. (2019). Countries Financial Development and Digital Readiness as Determinants of Financial Sector Innovativeness [Paper presentation]. Paper presented at the Proceedings of the 34rd International Business Information Management Association Conference, IBIMA 2019: Vision 2025: Education Excellence and Management of Innovations through Sustainable Economic Competitive Advantage, 13604-13619.

Lyeonov, S., Kuzmenko, O., Yarovenko, H. \& Dotsenko, T. (2019). The Innovative Approach to Increasing Cybersecurity of Transactions Through Counteraction to Money Laundering. Marketing and Management of Innovations, 3, 308-326. doi: http://doi.org/10.21272/mmi.2019.3-24.

Makarenko, I. O., \& Sirkovska, N. (2017). Transition to sustainability reporting: evidence from EU and Ukraine. Business Ethics and Leadership, Volume 1, Issue 1, 16 - 24. doi:10.21272/bel.2017.1-02.

Morscher, C., Horsch A., \& Stephan J. (2017). Credit Information Sharing and Its Link to Financial Inclusion and Financial Intermediation. Financial Markets, Institutions and Risks 1(1), 22-33. doi:10.21272/ fmir.1(3).22-33.2017.

Naghshpour, S. (2019). Determinants of economic growth rates of the newly formed countries of the former Soviet Union and Eastern Bloc. International Journal of Economic Policy in Emerging Economies, 12(5), 425-442. doi:10.1504/IJEPEE.2019.104638.

Natocheeva, N., Borodin, A., Rud, N., Kutsuri, G., Zholamanova, M., \& Namitulina, A. (2019). Development of tools for realizing the potential of financial stability of enterprises. Entrepreneurship and Sustainability Issues, 7(2), 16541665. doi:https://doi.org/10.9770/jesi.2019.7.2(60).

Pansuwong, W. (2020). Business model and business model innovation: scholarly incongruence and implications to entrepreneurial firms. International Journal of Trade and Global Markets, 13(1), 31-41. doi:https://10.1504/IJTGM.2020.10021939.

Petrushenko, Y. M., Kostyuchenko, N. M., \& Danko, Y. I. (2014). Conceptual Framework Of Local Development Financing In Undp Projects In Ukraine. Actual Problems in Economics, (159), 257.

Petrushenko, Y., Kozarezenko, L., Glinska-Newes, A., Tokarenko, M., \& But, M. (2018). The opportunities of engaging FinTech companies into the system of cross-border money transfers in Ukraine. Investment Management \& Financial Innovations, 15(4), 332 - 344. doi:http://dx.doi.org/10.21511/imfi.15(4).2018.27/.

Pilipenko, A. I., Dikhtiar, V. I., \& Baranova, N. M. (2019). 'Financial stability'safeguarding: modelling the Russian budgetary policy. International Journal of Economic Policy in Emerging Economies (IJEPEE), 12(1), 85-89. doi:10.1504/IJEPEE.2019.10019973.

Piontek, B. (2019). The theoretical basis of strategic security management for shaping the structural order and sustainability processes. Polish Journal of Management Studies, 20, 344 - 358.

Pitoňáková, R. (2019). Modelling impact of economic and demographic factors on personal saving rate in the euro area. International Journal of Trade and Global Markets, 12(3-4), 333-344.

Plastun, A., Makarenko, I., Yelnikova, Y., \& Sheliuk, A. (2018). Crisis and financial data properties: A persistence view. Journal of International Studies, 11(3), 284-294. doi:10.14254/2071-8330.2018/11-3/22.

Ramazanova, S., Kuchukova, N., Abdulova, G., Bulakbay, Z., \& Zhumanova, D. (2019). Financial incentives for increasing efficiebcy of activity of agro-industrial complex. Entrepreneurship and Sustainability Issues, 7(2), 15251541. doi:https://doi.org/10.9770/jesi.2019.7.2(51). 
Remeikiené, R., Gaspareniené, L., \& Sadeckas, A. (2019). The determinants of the competitiveness of Lithuanian export: macroeconomic approach. Business: Theory and Practice, 20, 170-178. doi:https://doi.org/10.3846/btp.2019.16.

Sebestova, J., Majerova, I., \& Szarowska, I. (2018). Indicators for assessing the financial condition and municipality management. Administratie si Management Public, (31), 97-110. doi:10.24818/amp/2018.31-07.

Shapovalova, I., Piiurenko, I., Husarina, N., Petrovska, S., \& Kravchenko, M. (2019). Process Factors of System Security of Trading Enterprises. Journal of Security \& Sustainability Issues, 9(1), $211 \quad$ - 255. doi:https://doi.org/10.9770/jssi.2019.9.1(16).

Shkodra, J. (2019). Financial performance of microfinance institutions in Kosovo. Journal of International Studies, 12(3), 31-37. doi:10.14254/2071-8330.2019/12-3/3.

Shkvarchuk, L., \& Slav'yuk, R. (2019). The Financial Behavior of Households in Ukraine. Journal of Competitiveness, 11(3), 144 - 159. doi:https://doi.org/10.7441/joc.2019.03.09/.

Shvindina, H. (2019). Coopetition as an emerging trend in research: perspectives for safety \& security. Safety, 5(3), 61. doi:https://doi.org/10.3390/safety5030061.

Simionescu, M., Popescu, J., \& Caraba-Meita, N. L. (2019). The Impact of Some Economic and Monetary Variables on the Real Gdp in CEE-5 Countries. Transformations in Business \& Economics, 18, 416 - 430.

Stefko, R., Jencova, S., Vasanicova, P., \& Litavcova, E. (2019). An evaluation of financial health in the electrical engineering industry. Journal of Competitiveness, 11(4), 144 - 160. doi:https://doi.org/10.7441/joc.2019.04.10.

Straßberger, M., \& Sysoyeva, L. (2016). Die aktuellen Entwicklungen der Bankenaufsicht im Lichte der Stabilität des Finanzsystems. Wirtschaftsdienst, 96(7), 486-491. doi: https://doi.org/10.1007/s10273-016-2003-3

Sukhonos, V., \& Makarenko, I. (2017). Sustainability reporting in the light of corporate social responsibility development: economic and legal issues. Problems and Perspectives in Management, (15, Iss. 1 (cont.)), 166-174. doi:http://dx.doi.org/10.21511/ppm.15(4).2017.08/.

Tsvetkova, L., Yurieva, T., Orlaniuk-Malitskaia, L., \& Plakhova, T. (2019). Financial Intermediary and Insurance Companies-Assessing Financial Stability. Montenegrin Journal of Economics, 15(3), 189-204. doi:10.14254/1800$\underline{5845 / 2019.15-3.14}$.

Vasileva, T., \& Lasukova, A. (2013). Empirical study on the correlation of corporate social responsibility with the banks efficiency and stability. Corporate ownership \& Control, 10(4), 86 - 93. doi:http://doi.org/10.22495/cocv10i4art7.

Vasilyeva, T., Bilan, S., Bagmet, K., \& Seliga, R. (2020). Institutional development gap in the social sector: Crosscountry analysis. Economics \& Sociology, 13(1), 271 - 294. doi:10.14254/2071-789X.2020/13-1/17.

Vasilyeva, T., Kuzmenko, O., Bozhenko, V., \& Kolotilina, O. (2019). Assessing the dynamics of bifurcation transformations in the economy. In SHS Web of Conferences (Vol. 65, p. 04006). EDP Sciences. doi: $10.1051 /$ shsconf/20196504006.

Vasilyeva, T., Sysoyeva, L., \& Vysochyna, A. (2016). Formalization of factors that are affecting stability of Ukraine banking system. Risk governance \& control: financial markets \& institutions, 6(4), 7-11. doi:https://10.22495/rcgv6i4art1.

Vasylyeva, T. A., Leonov, S. V., \& Lunyakov, O. V. (2014). Countercyclical capital buffer as a macroprudential tool for regulation of the financial sector. Actual Problems in Economics, (8), 278-283.

World Bank (2009), Good Practices for Financial Consumer Protection and Financial Literacy in Europe and Central Asia : A Diagnostic Tool. Washington DC: Private and Financial Sector Development Department Europe and Central Asia Region. The Borld Bank. Retrieved from URL: https://www.worldbank.org/en/topic/financialinclusion/publication/good-practices-in-consumerprotection-and-financial-literacy-in-eca/ .

WorldBank (2011). Good Practices for Financial Consumer Protection, Washington DC: International Bank for Reconstruction and Development. The World Bank. Retrieved from URL: https://www.worldbank.org/en/topic/financialinclusion/brief/2017-good-practices-for-financial-consumerprotection/. 
Yakubu, Z., Loganathan, N., Hassan, A. A. G., Mardani, A., \& Streimikiene, D. (2019). Financial and economic determinants of sustainable economic growth in Egypt, Nigeria and South Africa. Journal of International Studies, 12(4), 160-176. doi:10.14254/2071-8330.2019/12-4/11.

Yakymova, L., \& Kuz, V. (2019). The use of discriminant analysis in the assessment of municipal company's financial health. Economics \& Sociology, 12(2), 64-78. doi: 10.14254/2071-789X.2019/12-2/4.

Yelnikova, Y. (2014). Evaluation of the efficiency of state regulation on the derivatives market. Investment Management and Financial. 11(4), 85-91..

Yossifov, P., Das, U., \& Sundararajan, V. (2003). Cross-Country and Cross-Sector Analysis of Transparency of Monetary and Financial Policies. IMF Working Papers, 1-44. Retrieved from URL: https://www.imf.org/en/Publications/WP/Issues/2016/12/30/Cross-Country-and-Cross-Sector-Analysisof-Transparency-of-Monetary-and-Financial-Policies-16489/. 


\section{ANNEXES}

Table 1

Input variables

\begin{tabular}{|c|c|c|c|}
\hline № & Name of variable & Sense of variable & Legend \\
\hline 1 & Monitoring & $\begin{array}{l}\text { - Mystery/ incognito shopping; } \\
\text { - Interviews focus groups and consumer research; } \\
\text { - Requires FIs to report statistics on the number of } \\
\text { complaints; } \\
\text { - Operates call-centre to receive complaints; } \\
\text { - Monitors providers' advertisements, websites, etc.; } \\
\text { - On-site inspection and investigation of FIs }\end{array}$ & SCORE1 \\
\hline 2 & Enforcing & $\begin{array}{l}\text { - Issues warnings to financial institutions; } \\
\text { - Requires providers to refund excess charges; } \\
\text { - Requires providers to withdraw misleading advertisements; } \\
\text { - Imposes fines and penalties; } \\
\text { - Issues public notice of violations; } \\
\text { - Withdraws the offending provider's license to operate }\end{array}$ & SCORE2 \\
\hline 3 & Fair treatment & $\begin{array}{l}\text { - Deceptive advertising; } \\
\text { - Unfair or high-pressure selling practices; } \\
\text { - Abusive collection practices; } \\
\text { - Unauthorized use of client data or breach of client } \\
\text { confidential; } \\
\text { - No fair treatment provisions }\end{array}$ & SCORE3 \\
\hline 4 & Recourses & $\begin{array}{l}\text { - Certainly with financial ombudsman; } \\
\text { - Certainly with general ombudsman; } \\
\text { - Certainly, mediation service }\end{array}$ & SCORE4 \\
\hline 5 & $\begin{array}{l}\text { Standards for complaints } \\
\text { resolution }\end{array}$ & $\begin{array}{l}\text { - Procedures and processes; } \\
\text { - Timeliness of response; } \\
\text { - Accessibility }\end{array}$ & SCORE5 \\
\hline 6 & $\begin{array}{c}\text { Disclosure of information upon } \\
\text { opening deposit }\end{array}$ & $\begin{array}{l}\text { - Annual percentage yield and interest rate; } \\
\text { - Method of compounding; } \\
\text { - Minimum balance requirement; } \\
\text { - Fees and penalties; } \\
\text { - Early withdrawal penalties }\end{array}$ & SCORE6 \\
\hline 7 & $\begin{array}{l}\text { Disclosure of information upon } \\
\text { opening credit }\end{array}$ & $\begin{array}{l}\text { - Annual percentage rate using a standard formula; } \\
\text { - Fees; } \\
\text { - Computation method (avg. balance, interest); } \\
\text { - Required insurance }\end{array}$ & SCORE7 \\
\hline 8 & $\begin{array}{l}\text { Disclosure of general } \\
\text { information }\end{array}$ & $\begin{array}{l}\text { Plain language requirement; } \\
\text { Local language requirement; } \\
\text { Prescribed, standardized disclosure format; } \\
\text { Recourse rights and processes }\end{array}$ & SCORE8 \\
\hline 9 & $\begin{array}{l}\text { Periodic disclosure upon opening } \\
\text { deposit }\end{array}$ & $\begin{array}{l}\text { - Annual percentage yield calculation; } \\
\text { - Amount of interest earned; } \\
\text { - Fees imposed; } \\
\text { - Account balance }\end{array}$ & SCORE9 \\
\hline 10 & $\begin{array}{c}\text { Periodic disclosure upon opening } \\
\text { credit }\end{array}$ & $\begin{array}{l}\text { - All account transactions during the current period; } \\
\text { - Annual percentage rate; } \\
\text { - Interest charged for the period; } \\
\text { - Fees charged for the period; } \\
\text { - Minimum amount due; } \\
\text { - Date due; } \\
\text { - Outstanding balance }\end{array}$ & SCORE10 \\
\hline
\end{tabular}


Input indices

Table 2

\begin{tabular}{|c|c|c|c|c|c|c|c|c|c|c|c|c|c|c|c|c|c|}
\hline & \multicolumn{6}{|c|}{ Monitoring (6) } & \multicolumn{6}{|c|}{ Enforcing (6) } & \multicolumn{5}{|c|}{ Fair treatment (5) } \\
\hline & $\begin{array}{c}\text { Myster } \\
\text { y/ } \\
\text { incogni } \\
\text { to } \\
\text { shoppi } \\
\text { ng }\end{array}$ & $\begin{array}{c}\text { Intervie } \\
\text { ws, } \\
\text { focus } \\
\text { groups } \\
\text { and } \\
\text { consum } \\
\text { er } \\
\text { research }\end{array}$ & $\begin{array}{c}\text { Require } \\
\text { FIs to } \\
\text { report } \\
\text { statistics } \\
\text { on the } \\
\text { number } \\
\text { of } \\
\text { complai } \\
\text { nts } \\
\end{array}$ & $\begin{array}{l}\text { Operate } \\
\mathrm{s} \text { call } \\
\text { centre } \\
\text { to } \\
\text { receive } \\
\text { complai } \\
\text { nts }\end{array}$ & $\begin{array}{c}\text { Monitors } \\
\text { providers' } \\
\text { advertisem } \\
\text { ents, } \\
\text { websites, } \\
\text { etc. }\end{array}$ & $\begin{array}{c}\text { On-site } \\
\text { inspectio } \\
\mathrm{n} \text { and } \\
\text { investigat } \\
\text { ion of } \\
\text { FIs }\end{array}$ & \begin{tabular}{c|} 
Issue \\
warning \\
s to \\
financial \\
instituti \\
ons
\end{tabular} & $\begin{array}{c}\text { Requir } \\
\mathrm{e} \\
\text { provid } \\
\text { ers to } \\
\text { refund } \\
\text { excess } \\
\text { charges }\end{array}$ & \begin{tabular}{|c|} 
Require \\
providers \\
to \\
withdraw \\
misleading \\
advertisem \\
ents
\end{tabular} & $\begin{array}{l}\text { Impos } \\
\text { e fines } \\
\text { and } \\
\text { penalti } \\
\text { es }\end{array}$ & $\begin{array}{c}\text { Issue } \\
\text { public } \\
\text { notice } \\
\text { of } \\
\text { violatio } \\
\text { ns }\end{array}$ & $\begin{array}{l}\text { Withdr } \\
\text { aw the } \\
\text { offendi } \\
\text { ng } \\
\text { provide } \\
\text { r's } \\
\text { license } \\
\text { to } \\
\text { operate }\end{array}$ & $\begin{array}{c}\text { Decepti } \\
\text { ve } \\
\text { advertisi } \\
\text { ng }\end{array}$ & $\begin{array}{l}\text { Unfair } \\
\text { or } \\
\text { high- } \\
\text { pressu } \\
\text { re } \\
\text { selling } \\
\text { practic } \\
\text { es }\end{array}$ & $\begin{array}{l}\text { Abusiv } \\
\text { e } \\
\text { collecti } \\
\text { on } \\
\text { practic } \\
\text { es }\end{array}$ & $\begin{array}{c}\text { Unauthori } \\
\text { zed use of } \\
\text { client data } \\
\text { or breach } \\
\text { of client } \\
\text { confidenti } \\
\quad \text { ality }\end{array}$ & $\begin{array}{c}\text { No fair } \\
\text { treatme } \\
\text { nt } \\
\text { provisio } \\
\text { ns } \\
\end{array}$ \\
\hline $\begin{array}{l}\text { Afghanis } \\
\tan \end{array}$ & & & 1,00 & & & 1,00 & 1,00 & 1,00 & 1,00 & 1,00 & & & & & & & 1,00 \\
\hline Albania & & & & & 1,00 & 1,00 & 1,00 & & 1,00 & 1,00 & & 1,00 & 1,00 & 1,00 & 1,00 & 1,00 & \\
\hline Algeria & & & & & & 1,00 & 1,00 & 1,00 & & 1,00 & & 1,00 & 1,00 & 1,00 & & 1,00 & \\
\hline Anguilla & & & & & & & & & & & & & 1,00 & & & 1,00 & \\
\hline $\begin{array}{l}\text { Antigua } \\
\text { and } \\
\text { Barbuda }\end{array}$ & & & & & & & & & & & & & 1,00 & & & 1,00 & \\
\hline $\begin{array}{l}\text { Argentin } \\
\text { a }\end{array}$ & & 1,00 & & & 1,00 & 1,00 & 1,00 & & 1,00 & 1,00 & & & 1,00 & 1,00 & 1,00 & 1,00 & \\
\hline Armenia & & & & 1,00 & 1,00 & 1,00 & 1,00 & & 1,00 & 1,00 & 1,00 & 1,00 & 1,00 & 1,00 & 1,00 & 1,00 & \\
\hline Australia & 1,00 & 1,00 & & 1,00 & 1,00 & 1,00 & & & & & & & 1,00 & 1,00 & & & \\
\hline Austria & & & & 1,00 & 1,00 & 1,00 & 1,00 & & 1,00 & 1,00 & 1,00 & 1,00 & 1,00 & 1,00 & 1,00 & 1,00 & \\
\hline $\begin{array}{l}\text { Azerbaija } \\
\mathrm{n}\end{array}$ & & 1,00 & & 1,00 & 1,00 & 1,00 & 1,00 & 1,00 & 1,00 & 1,00 & & 1,00 & 1,00 & 1,00 & 1,00 & 1,00 & \\
\hline $\begin{array}{l}\text { Banglade } \\
\text { sh }\end{array}$ & & & & & & & & & & & & & & & & & 1,00 \\
\hline Belarus & & & & & & & & & & & & & 1,00 & & & & \\
\hline Belgium & & 1,00 & & 1,00 & 1,00 & & 1,00 & 1,00 & 1,00 & 1,00 & 1,00 & 1,00 & 1,00 & 1,00 & 1,00 & 1,00 & \\
\hline Benin & & & & & & 1,00 & & & & & & & & & & 1,00 & \\
\hline Bolivia & & 1,00 & 1,00 & 1,00 & 1,00 & & & & & 1,00 & & & 1,00 & & 1,00 & & \\
\hline $\begin{array}{l}\text { Bosnia } \\
\text { and } \\
\text { Herzego } \\
\text { vina }\end{array}$ & & & & & & & & & & & & & & & & & 1,00 \\
\hline $\begin{array}{l}\text { Botswan } \\
\text { a }\end{array}$ & & & & & 1,00 & 1,00 & 1,00 & 1,00 & 1,00 & 1,00 & & & 1,00 & & & 1,00 & \\
\hline Brazil & & & 1,00 & 1,00 & & 1,00 & 1,00 & & & 1,00 & & 1,00 & 1,00 & 1,00 & 1,00 & 1,00 & \\
\hline Bulgaria & & & & & & & & & & & & & 1,00 & 1,00 & 1,00 & 1,00 & \\
\hline
\end{tabular}

\begin{tabular}{|c|c|c|c|c|c|c|c|c|c|c|c|}
\hline \multirow[t]{2}{*}{ Country } & \multicolumn{3}{|c|}{ Recourses (3) } & \multicolumn{3}{|c|}{$\begin{array}{c}\text { Standards for complaints resolution } \\
\text { (3) }\end{array}$} & \multicolumn{5}{|c|}{ Disclosure of information upon opening deposit (5) } \\
\hline & $\begin{array}{l}\text { Yes, with } \\
\text { the financial } \\
\text { ombudsman }\end{array}$ & $\begin{array}{c}\text { Yes, with } \\
\text { the general } \\
\text { ombudsman }\end{array}$ & $\begin{array}{c}\text { Yes, } \\
\text { mediation } \\
\text { service }\end{array}$ & $\begin{array}{c}\text { Procedures } \\
\text { and } \\
\text { processes }\end{array}$ & $\begin{array}{c}\text { Timeliness } \\
\text { of } \\
\text { response }\end{array}$ & Accessibility & $\begin{array}{c}\text { Annual } \\
\text { percentage } \\
\text { yield and } \\
\text { interest } \\
\text { rate }\end{array}$ & $\begin{array}{c}\text { Method of } \\
\text { compounding }\end{array}$ & $\begin{array}{c}\text { Minimum } \\
\text { balance } \\
\text { requirement }\end{array}$ & \begin{tabular}{|l|} 
Fees and \\
penalties
\end{tabular} & $\begin{array}{c}\text { Early } \\
\text { withdrawal } \\
\text { penalties }\end{array}$ \\
\hline & & & 1,00 & 1,00 & 1,00 & 1,00 & 1,00 & 1,00 & 1,00 & 1,00 & 1,00 \\
\hline Afghanistan & & 1,00 & 1,00 & 1,00 & & 1,00 & 1,00 & & 1,00 & 1,00 & 1,00 \\
\hline Albania & & & & & 1,00 & 1,00 & 1,00 & 1,00 & 1,00 & 1,00 & 1,00 \\
\hline \multicolumn{12}{|l|}{ Algeria } \\
\hline \multicolumn{12}{|l|}{ Anguilla } \\
\hline $\begin{array}{l}\text { Antigua and } \\
\text { Barbuda }\end{array}$ & & 1,00 & & 1,00 & & 1,00 & 1,00 & 1,00 & 1,00 & 1,00 & 1,00 \\
\hline Argentina & 1,00 & & & 1,00 & 1,00 & 1,00 & 1,00 & 1,00 & 1,00 & 1,00 & 1,00 \\
\hline Armenia & 1,00 & & & 1,00 & 1,00 & & & & & & \\
\hline Australia & 1,00 & 1,00 & & 1,00 & & & 1,00 & 1,00 & & 1,00 & 1,00 \\
\hline Austria & & 1,00 & & & 1,00 & 1,00 & 1,00 & 1,00 & 1,00 & 1,00 & 1,00 \\
\hline \multicolumn{12}{|l|}{ Azerbaijan } \\
\hline Bangladesh & & & & & & & 1,00 & & & & \\
\hline Belarus & & & 1,00 & 1,00 & 1,00 & 1,00 & 1,00 & 1,00 & & 1,00 & 1,00 \\
\hline \multicolumn{12}{|l|}{ Belgium } \\
\hline Benin & & 1,00 & & 1,00 & 1,00 & 1,00 & 1,00 & & & 1,00 & \\
\hline \multicolumn{12}{|l|}{ Bolivia } \\
\hline $\begin{array}{l}\text { Bosnia and } \\
\text { Herzegovina }\end{array}$ & 1,00 & & & 1,00 & 1,00 & 1,00 & 1,00 & 1,00 & & & \\
\hline Botswana & 1,00 & 1,00 & & 1,00 & 1,00 & 1,00 & & & & 1,00 & \\
\hline Brazil & 1,00 & & & 1,00 & 1,00 & 1,00 & 1,00 & 1,00 & 1,00 & & 1,00 \\
\hline
\end{tabular}




\begin{tabular}{|c|c|c|c|c|c|c|c|c|c|c|c|c|}
\hline \multirow[t]{2}{*}{ Country } & \multicolumn{4}{|c|}{$\begin{array}{c}\text { Disclosure of information upon opening } \\
\text { credit (4) }\end{array}$} & \multicolumn{4}{|c|}{ Disclosure of general information (4) } & \multicolumn{4}{|c|}{$\begin{array}{c}\begin{array}{c}\text { Periodic disclosure upon opening } \\
\text { deposit (4) }\end{array} \\
\end{array}$} \\
\hline & $\begin{array}{c}\text { Annual } \\
\text { percentage } \\
\text { rate using a } \\
\text { standard } \\
\text { formula } \\
\end{array}$ & Fees & $\begin{array}{l}\text { Computation } \\
\text { method (avg. } \\
\text { balance, } \\
\text { interest) }\end{array}$ & $\begin{array}{l}\text { Required } \\
\text { insurance }\end{array}$ & $\begin{array}{c}\text { Plain } \\
\text { language } \\
\text { requirement }\end{array}$ & $\begin{array}{c}\text { Local } \\
\text { language } \\
\text { requirement }\end{array}$ & $\begin{array}{l}\text { Prescribed, } \\
\text { standardized } \\
\text { disclosure } \\
\text { format }\end{array}$ & $\begin{array}{c}\text { Recourse } \\
\text { rights and } \\
\text { processes }\end{array}$ & $\begin{array}{c}\text { Annual } \\
\text { percentage } \\
\text { yield } \\
\text { calculation }\end{array}$ & $\begin{array}{c}\text { Amount } \\
\text { of } \\
\text { interest } \\
\text { earned }\end{array}$ & $\begin{array}{c}\text { Fees } \\
\text { imposed }\end{array}$ & $\begin{array}{c}\text { Account } \\
\text { balance }\end{array}$ \\
\hline Afghanistan & & & & & 1,00 & 1,00 & 1,00 & 1,00 & 1,00 & 1,00 & 1,00 & 1,00 \\
\hline Albania & 1,00 & 1,00 & 1,00 & & 1,00 & 1,00 & 1,00 & & 1,00 & 1,00 & 1,00 & 1,00 \\
\hline Algeria & 1,00 & 1,00 & 1,00 & 1,00 & 1,00 & 1,00 & & 1,00 & 1,00 & 1,00 & 1,00 & 1,00 \\
\hline \multicolumn{13}{|l|}{ Anguilla } \\
\hline \multicolumn{13}{|l|}{$\begin{array}{l}\text { Antigua and } \\
\text { Barbuda }\end{array}$} \\
\hline Argentina & 1,00 & 1,00 & 1,00 & 1,00 & 1,00 & 1,00 & & & 1,00 & 1,00 & 1,00 & 1,00 \\
\hline Armenia & 1,00 & 1,00 & 1,00 & 1,00 & 1,00 & 1,00 & 1,00 & 1,00 & 1,00 & 1,00 & 1,00 & 1,00 \\
\hline \multicolumn{13}{|l|}{ Australia } \\
\hline Austria & 1,00 & 1,00 & 1,00 & 1,00 & 1,00 & 1,00 & & & & & & \\
\hline Azerbaijan & 1,00 & 1,00 & 1,00 & 1,00 & 1,00 & 1,00 & & 1,00 & 1,00 & 1,00 & 1,00 & 1,00 \\
\hline \multicolumn{13}{|l|}{ Bangladesh } \\
\hline Belarus & 1,00 & & & & & & & & 1,00 & 1,00 & & 1,00 \\
\hline Belgium & 1,00 & 1,00 & & & 1,00 & 1,00 & 1,00 & & & & & \\
\hline Benin & & & & & 1,00 & & 1,00 & & & & 1,00 & 1,00 \\
\hline Bolivia & 1,00 & & 1,00 & & & 1,00 & & 1,00 & & & & 1,00 \\
\hline \multicolumn{13}{|l|}{$\begin{array}{l}\text { Bosnia and } \\
\text { Herzegovina }\end{array}$} \\
\hline Botswana & 1,00 & 1,00 & & 1,00 & 1,00 & & 1,00 & & & & & \\
\hline Brazil & 1,00 & 1,00 & & & 1,00 & 1,00 & & 1,00 & 1,00 & & 1,00 & \\
\hline Bulgaria & 1,00 & 1,00 & 1,00 & 1,00 & 1,00 & 1,00 & & 1,00 & & & & \\
\hline
\end{tabular}

\begin{tabular}{|c|c|c|c|c|c|c|c|}
\hline \multirow[t]{2}{*}{ Country } & \multicolumn{7}{|c|}{ Periodic disclosure upon opening credit (7) } \\
\hline & $\begin{array}{l}\text { All account } \\
\text { transactions } \\
\text { during the } \\
\text { current period }\end{array}$ & $\begin{array}{c}\text { Annual } \\
\text { percentage } \\
\text { rate }\end{array}$ & $\begin{array}{l}\text { Interest } \\
\text { charged for } \\
\text { the period }\end{array}$ & $\begin{array}{c}\text { Fees } \\
\text { charged for } \\
\text { the period }\end{array}$ & $\begin{array}{l}\text { Minimum } \\
\text { amount due }\end{array}$ & Date due & $\begin{array}{c}\text { Outstanding } \\
\text { balance }\end{array}$ \\
\hline Afghanistan & 1,00 & 1,00 & 1,00 & 1,00 & & & \\
\hline Albania & & 1,00 & 1,00 & 1,00 & 1,00 & 1,00 & 1,00 \\
\hline Algeria & 1,00 & 1,00 & 1,00 & 1,00 & 1,00 & 1,00 & 1,00 \\
\hline \multicolumn{8}{|l|}{ Anguilla } \\
\hline \multicolumn{8}{|l|}{$\begin{array}{l}\text { Antigua and } \\
\text { Barbuda }\end{array}$} \\
\hline Argentina & 1,00 & 1,00 & 1,00 & 1,00 & 1,00 & 1,00 & 1,00 \\
\hline Armenia & 1,00 & 1,00 & 1,00 & 1,00 & 1,00 & 1,00 & 1,00 \\
\hline \multicolumn{8}{|l|}{ Australia } \\
\hline \multicolumn{8}{|l|}{ Austria } \\
\hline Azerbaijan & 1,00 & 1,00 & 1,00 & 1,00 & 1,00 & 1,00 & 1,00 \\
\hline \multicolumn{8}{|l|}{ Bangladesh } \\
\hline Belarus & & 1,00 & 1,00 & & 1,00 & 1,00 & 1,00 \\
\hline Belgium & 1,00 & 1,00 & 1,00 & 1,00 & 1,00 & 1,00 & 1,00 \\
\hline Benin & 1,00 & & & 1,00 & & & 1,00 \\
\hline Bolivia & & 1,00 & & & 1,00 & 1,00 & 1,00 \\
\hline \multicolumn{8}{|l|}{$\begin{array}{l}\text { Bosnia and } \\
\text { Herzegovina }\end{array}$} \\
\hline \multicolumn{8}{|l|}{ Botswana } \\
\hline Brazil & & 1,00 & & 1,00 & & & \\
\hline Bulgaria & 1,00 & 1,00 & 1,00 & 1,00 & 1,00 & 1,00 & 1,00 \\
\hline
\end{tabular}


Description of the adhering degree of $S C O R E_{1}-S C O R E_{10}$

Table 3

\begin{tabular}{|c|c|}
\hline \multicolumn{2}{|c|}{ Monitoring } \\
\hline Pc & $1-2$ \\
\hline $\mathrm{Bc}$ & $3-5$ \\
\hline $\mathrm{Fc}_{\mathrm{c}}$ & 6 \\
\hline \multicolumn{2}{|c|}{ Enforcing } \\
\hline Pc & $1-2$ \\
\hline $\mathrm{Bc}$ & $3-5$ \\
\hline Fc & 6 \\
\hline \multicolumn{2}{|c|}{ Fair treatment } \\
\hline Pc & $1-2$ \\
\hline $\mathrm{Bc}$ & $3-4$ \\
\hline$\overline{F c}$ & 5 \\
\hline \multicolumn{2}{|c|}{ Recourses } \\
\hline Pc & 1 \\
\hline $\mathrm{Bc}$ & 2 \\
\hline Fc & 3 \\
\hline \multicolumn{2}{|c|}{ Standards for complaints resolution } \\
\hline Pc & 1 \\
\hline $\mathrm{Bc}$ & 2 \\
\hline$\overline{F c}$ & 3 \\
\hline \multicolumn{2}{|c|}{ Disclosure of information upon opening deposit } \\
\hline Pc & $1-2$ \\
\hline $\mathrm{Bc}$ & $3-4$ \\
\hline Fc & 5 \\
\hline \multicolumn{2}{|c|}{ Disclosure of information upon opening credit } \\
\hline Pc & 1 \\
\hline $\mathrm{Bc}$ & $2-3$ \\
\hline $\mathrm{Fc}_{\mathrm{c}}$ & 4 \\
\hline \multicolumn{2}{|c|}{ Disclosure of general information } \\
\hline Pc & 1 \\
\hline $\mathrm{Bc}$ & $2-3$ \\
\hline$\overline{F c}$ & 4 \\
\hline \multicolumn{2}{|c|}{ Periodic disclosure upon opening deposit } \\
\hline Pc & 1 \\
\hline $\mathrm{Bc}$ & $2-3$ \\
\hline$\overline{F c}$ & 4 \\
\hline \multicolumn{2}{|c|}{ Periodic disclosure upon opening credit } \\
\hline Pc & $1-2$ \\
\hline $\mathrm{Bc}$ & $3-6$ \\
\hline$\overline{F c}$ & 7 \\
\hline
\end{tabular}




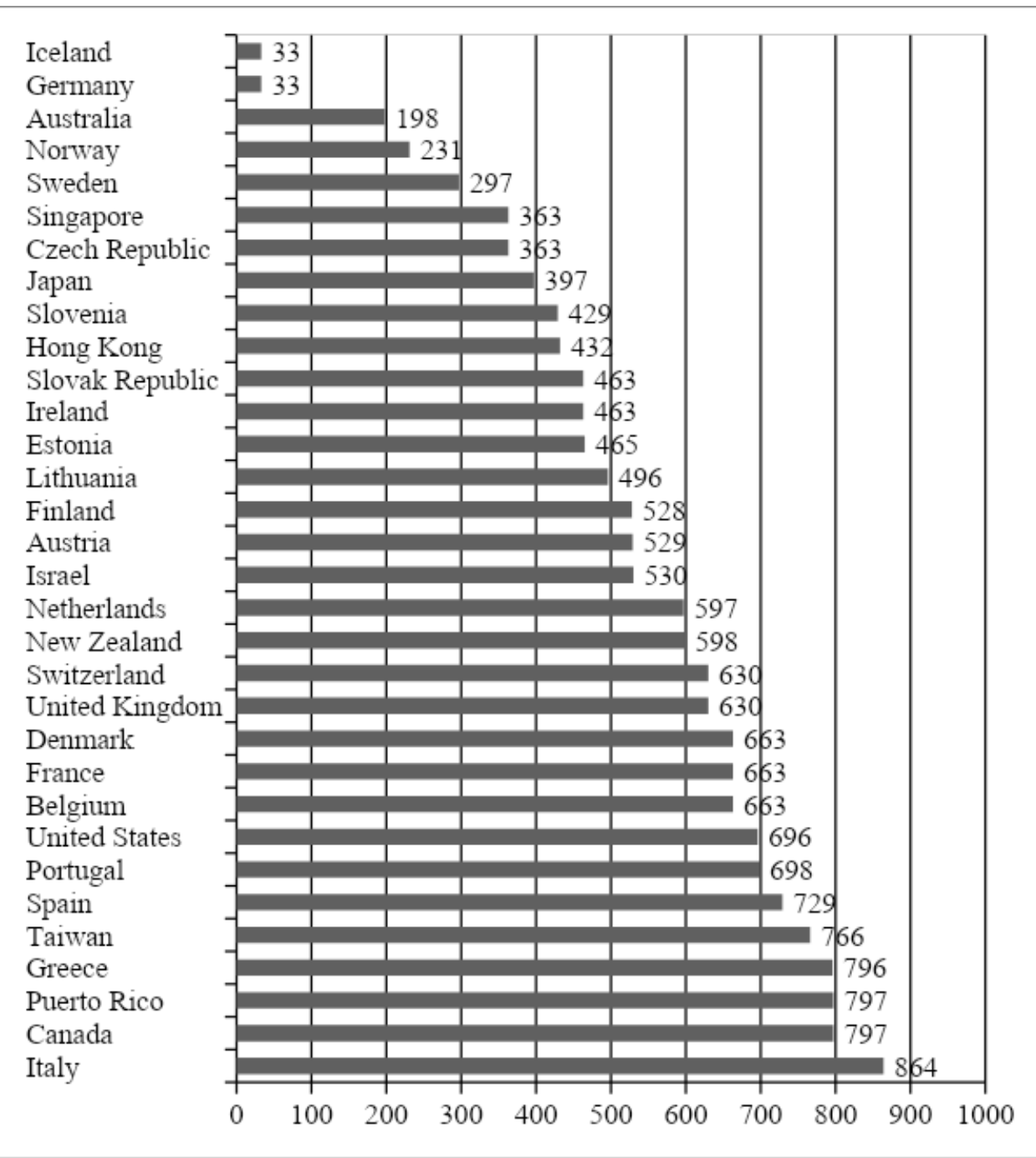

Fig 1a. The obtained results of the financial security level for countries with high economic development 
Tetyana Vasylieva, Oktawia Jurgilewicz,

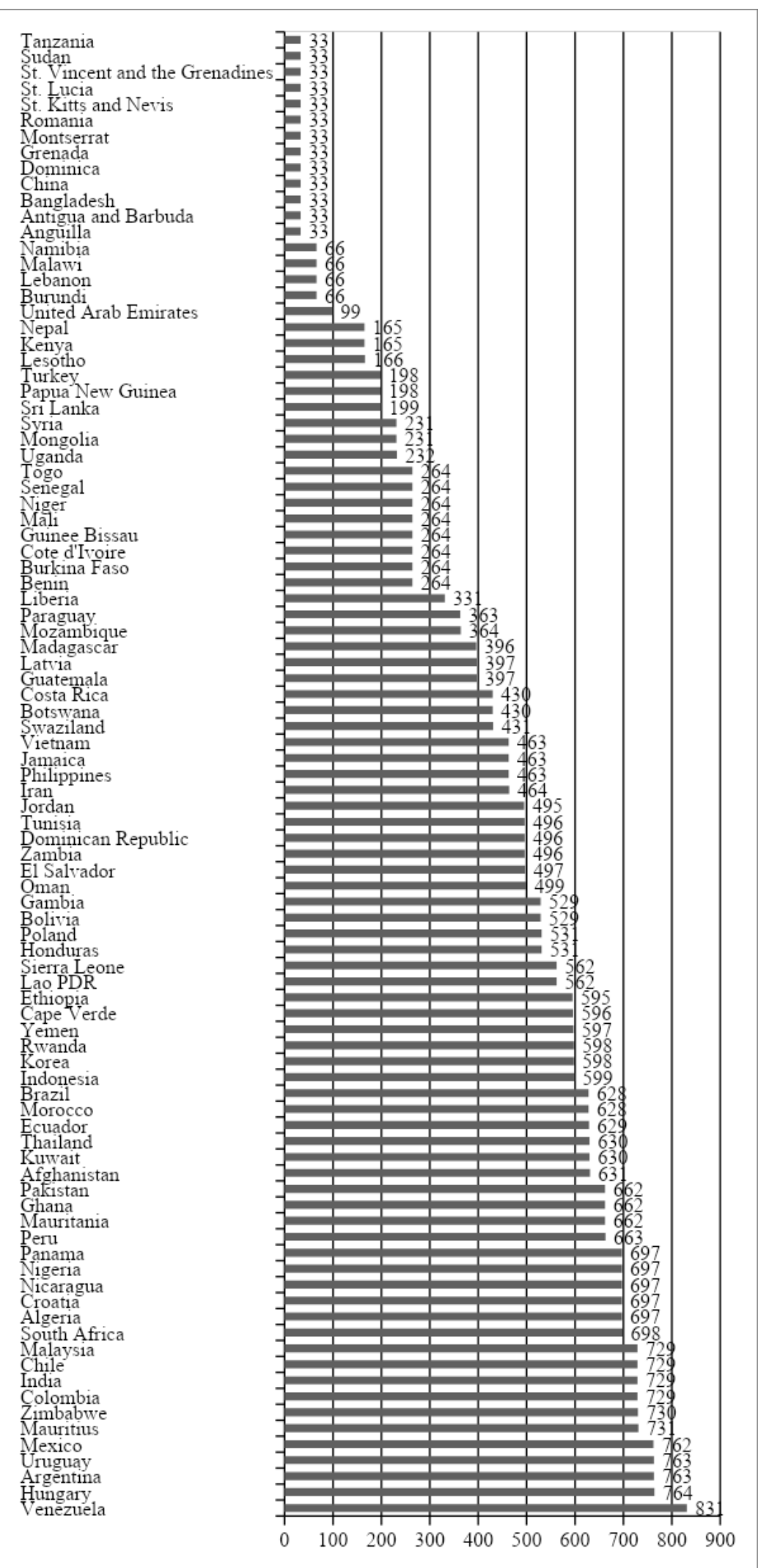

Fig 1b. The obtained results of the country's financial security level for EIT countries 


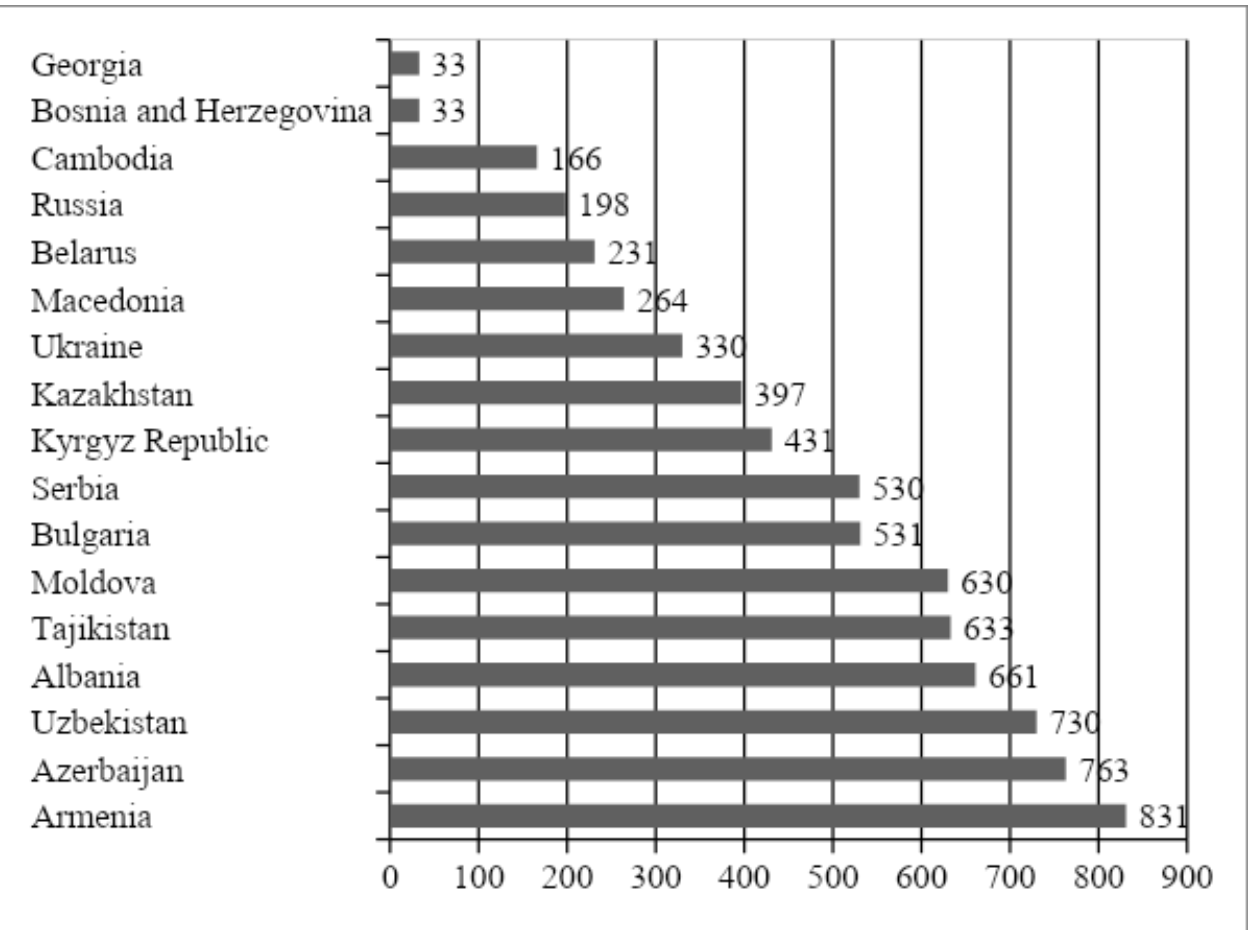

Fig 1c. The obtained results of the financial security level for developing countries 